\title{
Evil and Meaningful Existence: A Humanistic Response through the Lens of Classical Theism
}

\author{
Bonaventure B. Gubazire1 \\ 1 Department of Philosophy and Social Sciences, Spiritan University, Ejisu - Ghana.
}

\begin{abstract}
This study modestly proposes a humanistic response as supplementary to classical theism in addressing concrete cases of gratuitous human suffering. Classical theism places evil in God's divine plan of salvation for humanity. There is thus a good reason behind human suffering. However, there are times when suffering is so intense and dehumanising that any attempt to justify it in terms of God's love for humanity fails to make sense in the lives of most people. It is at this point that a humanistic response, coupled with spiritual guidance, becomes relevant. A humanistic response expresses itself through an African ethical theory and practice known as Ubuntu. It pivots on key human values such as love, compassion, trust, consideration, dialogue, forgiveness, solidarity, justice as equity, etc. It is in a spirit of togetherness that most existential challenges can be squarely faced to make human life more meaningful. Ultimately, a humanistic response recommends a change of attitude towards human suffering. Suffering should be seen as part of what it means to $B e$ in this finite world, and that it is in one's struggle towards the heights that one finds a sense in living.
\end{abstract}

Keywords: Evil, Classical Theism, Humanistic Response (Ubuntu), Attitudinal

Change.

(C) 2021 The Author(s). Published and Maintained by Noyam Publishers.

This is an open access article under the CCBY license (http://creativecommons.org/licenses/by/4.0/).

\section{INTRODUCTION}

Is it possible to lead a meaningful life despite the presence of evil in this world? Evil, understood as gratuitous human suffering, is a "concrete fact of human life." Evils such as war, terrorism, material misery, hunger, inhuman torture, human trafficking, corruption, natural calamities, incurable diseases, pandemics such as Covid-19, pose a serious challenge to human existence, and, quite often, inflict immense suffering on the lives of countless innocent people. No one can measure the amount of pain experienced by one who loses a beloved one. Many a time, the headlines of newspapers and the news items on television send chills down one's spine. Paradoxically, evil as a topic fascinates and sensationally appeals to a larger percentage of people's attention. Many people appear to be more interested in reporting, watching or reading about what is out of the ordinary, especially news about violence.

The presence of evil becomes more problematic when one believes in a God of love and might. If God is so powerful and so loving, why is there evil? Why does God allow innocent people to suffer unjustly? Is

\footnotetext{
1 Marilyn McCord Adams, Horrendous Evils and the Goodness of God (Ithaca and London: Cornell University Press, 1999$), 1$.

"Gratuitous suffering" represents a deplorable human experience whereby one is compelled to undergo pain or anguish against one's will. Keith Chrzan, "When is a gratuitous evil really gratuitous?" International Journal for Philosophy of Religion 24:1/2 (July-September 1988): 87-91.
} 
God not as powerful as He is believed to be? Non-believers may also ask: How come reality cannot always be how it ought to be? How come things fail to follow their natural order? How come humans sometimes do certain things which they fully know they ought not to do? Why is it extremely difficult to quit certain addictions, say, to alcohol, cigarettes, gambling, drugs, internet games, pornography, etc.? At the summit of all, fundamental questions arise: Can evil ever be totally "silenced"? Can mankind imagine a world where there is no suffering? What if evil was an invincible reality in this world; would it still be possible to lead a meaningful life? How can believers reconcile the presence of human suffering with the existence of a loving and powerful God?

This paper modestly attempts to shed some light on these questions. It firstly analyses the problem of evil by placing it in the context of gratuitous human suffering. Secondly, it shows how classical theism, as presented in the works of Augustine and Aquinas, attempts to reconcile the presence of evil with a loving and powerful God. Thirdly, it proposes a humanistic response, expressed through the ethics of Ubuntu, as a supplementary approach in addressing concrete cases of needless human suffering. Fourthly and lastly, this paper recommends what is termed "attitudinal change" towards human suffering as a means to cope with those existential challenges that defy human ingenuity. It is by consenting to the things that cannot be changed that human life is likely to be more meaningful despite the presence of instances of evil.

\section{Evil}

The term "evil" is generally controversial. "Evil" can mean different things to the same people at the same time. In the context of this study, "evil" designates actions, attitudes, events, situations... that cause undeserved or gratuitous human suffering. ${ }^{2}$ An act or event is evil precisely because it prompts pointless human suffering. ${ }^{3}$ Three kinds of evil may be enumerated, namely, (1) moral evil, (2) physical (natural) evil, and (3) metaphysical evil. Moral evil represents the pain and suffering directly triggered by human beings and inflicted on fellow human beings. Moral evils include vices such as murder, corruption, wars, human slavery, sexual abuses, human trafficking, witchcraft, and so on. These evils reflect the perversity of human thoughts and actions.

Natural evil denotes pain and suffering springing from natural phenomena such as hurricanes, earthquakes, diseases, storms, droughts, tornadoes, etc. Natural evils are generally conceived of as products of natural processes. They supposedly occur independently of human intervention. Natural evil, also known as physical evil, implies some bodily deformities like albinism, blindness and other physical imbalances believed to be naturally caused. Another kind of evil closely related to natural evil is "metaphysical evil." This represents the pain and suffering allied to the fleetingness of reality. All that exists [but not as ipsum esse subsistens] has an end. ${ }^{4}$ Nothing is eternal except Eternity itself. From an empirical perspective, everything passes away. Buddhist philosophers use the term anicca to describe this fleetingness of reality. ${ }^{5}$ No matter how beautiful human life is, death will eventually strike. Pleasure or joy is potential suffering because it will unavoidably be over and lead to dissatisfaction. The fleetingness or diminishment of reality, in most cases, leads to suffering. Take the case of sufferings related to old age. Think of death itself, especially when every human effort has been extended to save lives.

The discussion about the problem of evil as gratuitous or needless suffering is not a new phenomenon. Biblical authors and Jewish thinkers struggled with it in an impressive manner. A Jewish sage wondered why some righteous men were getting what the wicked deserve, and wicked men getting what the righteous deserve (Ecc 8:14). Job also asked why he, an innocent man, suffered unjustly (Job 3). Still more, one of the Psalmists wondered whether God really cared for His people, because the wicked, especially the exploiters of the poor, had become more successful in life than the virtuous ones (Psa 10:1-4).

In contemporary times, the problem of gratuitous human suffering continues to undermine the faith of most believers in a theistic God. When faced with a painful situation regarding his three-year-old son's generative disease, Rabbi Harold Samuel Kushner wondered why God would allow bad things to happen to

\footnotetext{
John Hick, Evil and the God of Love, Second Edition (New York: Palgrave Publisher Ltd, 1985), 12-13.

3 The researcher is nonetheless aware that some acts are intrinsically evil whether they cause unjustified suffering or not. For example, stealing from a person who remains unaware of it. This is not the conception of evil examined in this study.

4 Ipsum esse subsistens refers to the existence of God. Only God is "His own existence." Thomas Aquinas, Summa Theologica, translated by Fathers of the English Dominican Province (Westminster: Christian Classics, 1981), Vol. Q. 3, art. 4 of part I, 17.

5 Sebastian Gab, "Why do we suffer? Buddhism and the problem of evil," Philosophy Compass 10:5 (2015): $345-353$.
} 
good people. ${ }^{6}$ John Hick sees the problem of undeserved suffering as a major stumbling block to the belief in a God of love. ${ }^{7}$ For William Hasker, evil is a stepping stone for atheists to deflate and deliberately attack theistic beliefs. $^{8}$

Certainly, not all suffering is evil. Suffering can be constructively "useful." Suffering may positively build or shape one's character. People who have not experienced some form of suffering may lack an essential ingredient in their human development. For Friedrich Nietzsche, suffering makes one stronger. ${ }^{9}$ For Soren Kierkegaard, suffering may be a necessary condition for spiritual growth. ${ }^{10}$ Suffering can lead to a deeper level of self-awareness and self-understanding. Human experience also shows that a successful or flourishing life is, quite often, an outcome of painful experiences characterised by an amount of struggle and the possibility of failure, and all the suffering that derives from it.

Nonetheless, suffering bears the name "evil" when it is experienced as undeserved, when one is rendered passive and impotent before dehumanising situations. One finds oneself set against the flow of life. Imagine extreme cases of violence such as rape, torturing innocent civilians by amputating their arms, forcing an unborn child from the mother's womb, etc. Remarkably, classical theism, without attributing evil to God, still places evil in God's divine plan of salvation for humanity. How is this so?

\section{Classical Theism on Evil}

Classical theism, as mainly reflected in the works of Augustine and Aquinas, posits and defends the existence of a God believed to be omnipotent (all-powerful), omniscient (all-knowing) and omnibenevolent (all-loving, all-good). ${ }^{11}$ Most theistic religions such as Judaism, Christianity and Islam uphold this conception of God. God is the creator and sustainer of the Universe. For Augustine, since God is good, it logically follows that the things God has created are also good. ${ }^{12}$ Evil is thus not a creation of God. Evil is rather a distortion of good. Similarly, Aquinas understands evil as loss or privation of good (privatio boni). ${ }^{13}$ Evil distorts the form of an entity by diverting it from its proper end. Literally speaking, evil has no objective existence. It is simply parasitic upon the good. Both Augustine and Aquinas suggest that evil can only be recognised in the framework of a prior appreciation of the good.

How then is it possible to reconcile human suffering with the goodness and powerfulness of God? Classical theism diligently posits a number of logical solutions known as "theodicies" or justifications of God's permission of evil. ${ }^{14}$ This study limits itself to three classical theodicies. These are (1) free-will theodicy, (3) greater goods theodicy, and (3) unknown reasons theodicy. These three, in some way, encompass the other theodicies such as natural law theodicy, felix culpa theodicy, the many universe solution theodicy, etc. Beneath these classical theodicies is the teaching that God does not "will" evil but may "permit" it for the well-being of humanity. God permits evil by "willing the good to which such evils are attached." 15 Thus, God has a hand in whatever happens in the Universe.

In the first place, advocates of free-will theodicy claim that God may permit evil to allow human beings to exercise their freedom or self-determination. ${ }^{16}$ Human beings can determine themselves only if they have free-will. Man would not lead a normal life if he were not endowed with free-will. He would equally not be a moral agent without free-will. Free-will is the backbone of the human capacity to judge rightly or

\footnotetext{
6 Harold S. Kushner, When Bad Things Happen to Good People (New York: Christian Book Distributors, 2014).

Hick, Evil and the God of Love, ix.

8 William Hasker, "The Problem of Evil in Process and Classic Free Will Theism," Process Studies 29:2 (2000): 194.

9 Friedrich Nietzsche, "Epigrams and Arrows 8," Twilight of Idols, translator, Richard Polt (Indianapolis: Hackett Publishing Company, Inc.1997 [1889], 5.

${ }^{10}$ Soren Kerkegaard, Upbuilding Discourses in Various Spirits, ed. Edna Hong (Princeton: Princeton University Press, 2009), 248263.

11 Aquinas, Summa Theologica, Vol. I, Qs. 6, 8, 14, 25,103.

12 Augustine, Saint Augustine Confessions, translated by R.S. Pine-Coffin (Harmondsworth: Penguin Books Ltd, 1973), Book VII, Chapter 5.

13 Aquinas, Summa Theologica, Vol. 1, Q.48, art. 1 of part 1, 248-249.

${ }_{14}$ Aquinas, Summa Theologica, Vol. 1, Q.19, art. 2 of part 1, 104.

15 Aquinas, Summa Theologica, Vol. 1, Q.19, art. 2 of part 1, 104.

${ }^{16}$ Augustine, On the Free Choice of the Will, On Grace and Free Choice, and Other Writings, edited and translated by Peter King (Cambridge: Cambridge University Press, 2010), Book 2. 20.54.
} 
wrongly. Evil occurs when man misuses his free-will by judging wrongly and acting immorally. God could not have created man in such a way that there is no chance of man going wrong or being bad. ${ }^{17}$ God created man with free-will so that man could freely respond in love, faithfulness or obedience to God. God's direct intervention in averting moral evil would restrict human freedom.

Secondly, some classical-theistic thinkers uphold that to achieve certain goods an amount of suffering is required. Richard Swinburne calls them "greater goods." ${ }^{18}$ John Hick uses the expression "soul-making" to describe the nature and finality of these goods. ${ }^{19}$ The underlying argument is that God may allow evil in the world so that man might achieve moral or spiritual growth through his struggle to overcome suffering. Most moral virtues such as compassion, generosity, solidarity, care, courage, self-sacrifice, and so on, are only possible in a world where there is evil and suffering. God may permit evil in the world so that man achieves moral or spiritual growth. For Saint Irenaeus, neither the world nor man were made perfect, but man has a potential for perfection. ${ }^{20}$ Evil or suffering may be [to use Hick's term] a soul-making process or an occasion for man to orient himself towards moral perfection. Thus, some evils serve as moments of grace for the attainment of greater goods.

Thirdly and lastly, some classical-theistic thinkers claim that God may permit evil to strike humanity for reasons unknown to human beings but known to God alone. Behind this view is the conviction that mankind can never exactly know or absolutely predict the "thoughts" of God. Some Biblical authors unveil this fact. Job, for instance, could not conceive of the reason for the horrendous evils that befell him (Job 1:13; 2:1-11). For the Prophet Isaiah, God's thoughts escape human knowability. God's ways remain mysterious and perplexing (Isa 55:8-10). This Biblical message suggests that human reason is too small to capture the greatness of Divine wisdom. Thus said, God may allow evil to strike humanity for reasons unknown to man but known to God alone. As such, humility or the "wisdom of unknowing" seems to be the appropriate way to approach or talk about God. ${ }^{21}$

There is no doubt that this classical teaching on evil logically reconciles the presence of evil in this world with a loving and powerful God. Evil is not a creation of God. What God created is all good. Evil can only exist parasitically upon good. God does not "will" evil but may "permit" it for the well-being of humanity. There is thus a reason behind human suffering. While the conviction that God has a hand in whatever happens in the Universe might give a sense of strength, comfort and hope to most believers, it nonetheless arouses ethical or humanistic concerns. Would it really make sense to tell someone tormented by intense and dehumanising pain, for instance, those starving in refugee camps or an elderly widow who has just lost her only son, that God deliberately intends her agony to allow her to attain a higher level of moral or spiritual growth? It feels existentially and pastorally awkward to confidently justify dehumanising evils in terms of God's divine wisdom and love for humanity.

But could there be another approach to the problem of evil that would loyally supplement classical theodicies without justifying evil, appeal to non-believers in God, and respond to the concrete situation of gratuitous human suffering? This study modestly proposes a humanistic response expressed through the African ethics of Ubuntu.

\section{A Humanistic Response as Ubuntu in the Face of Human Suffering}

A humanistic response represents spontaneous human attitudes, dispositions and actions geared towards human and societal flourishing. It pivots on life-saving human values such as love, compassion, consideration, hospitality, solidarity, dialogue, friendliness, forgiveness, supererogation, justice as equity, etc. A humanistic response defended in this paper is not an ideology or a system of thought. It should neither be associated with secular humanism or naturalism, ideologies that tend to prioritise human freedom or natural laws [in the governing of the universe and human nature] as opposed to spiritual beliefs. A humanistic response goes beyond normative structures of conventional morality, but does not ignore them. Normative structures

\footnotetext{
17 Alvin Plantinga, God, Freedom, and Evil (New York, 1974), 49.

${ }_{18}$ Richard Swinburne, Providence and the Problem of Evil (Oxford: Oxford University Press, 1988), 605.

19 Hick, Evil and the God of Love, 334.

20 Irenaeus, Against Heresies, Book 4. Chapter 39.2, (North Charleston SC: Ex Fontibus Company, 2015).

${ }^{21}$ Marie Majorie R. Purino, “On Wisdom: Revisiting Chandogya Upanishad, Cusanus' Visio Intellectualis, and Heidegger's Aletheia," PHAVISMINDA Journal 14 (May 2015): 72.
} 
are indispensable in bringing about justice and peaceful-coexistence. Beneath a humanistic response is a conviction that it is in a spirit of togetherness, expressed through compassion, genuine dialogue and solidarity, that most existential challenges can be squarely faced to make human life more meaningful. This spirit of togetherness is part of what is philosophically known as Ubuntu.

Ubuntu represents [among other things] mankind's "inherent goodness" or "inherent-impulse-forresponsibility" expressed through a spontaneous inclination to attend to the needs of fellow human beings. Ubuntu, as an ethical theory and practice, mainly operates at the level of sensibility (intuition) prior to making references to legal or conventional morality. It stems from the existential fact that one's life is fundamentally owed to others. Etymologically, the concept of Ubuntu can be traced to the Bantu people of Central, Eastern and Southern Africa. Although these people have different linguistic dialects, they, nonetheless, share a common language characterized by the root word $n t u$ or $n h u$. This root $n t u$ or $n h u$ is reflected in the Bantu words for a human being, namely, umuntu, munthu, mtu, omuntu, munhu...depending on one's linguistic affiliation. To be truly human is to embody Ubuntu. While the term Ubuntu is a Bantu word, the concept itself runs through almost all African philosophical traditions. In Northern Africa, the Arabic term Insaniyya [translated as "humanness"] seems to represent the reality of Ubuntu. In Western Africa, particularly in the Igbo language of Nigeria, the term Ibummadu, somehow, carries the same weight as Ubuntu. It is Ibummadu (humanness) that lays the ground for Umunna (brotherhood or human interconnectedness). ${ }^{22}$

The understanding of Ubuntu as an inherent-impulse-for-responsibility can be mainly identified in the works of Claire Oppenheim, Desmond Tutu, and Nelson Mandela. Oppenheim describes Ubuntu as an "innate duty" or a "spirit from within," that drives man to become fully human and to be attentive to the needs of fellow human beings. ${ }^{23}$ Tutu considers Ubuntu as the "essence of what it is to be human." ${ }^{24}$ To be truly human is to embody certain qualities judged suitable for living with other human beings. Tutu, in some way, connects the concept of Ubuntu with God's image (Imago Dei) in man. ${ }^{25}$ Ubuntu insistently reminds mankind that they belong to God. Mankind is called to love God through worship and to love their neighbour through acts of charity.

Perhaps, the most suitable description of Ubuntu, as an inherent-impulse-for-responsibility, can be traced to the wisdom of Mandela. When asked to define Ubuntu, Mandela sagely narrates a story:

A traveller through a country would stop at a village and he didn't have to ask for food or for water.

Once he stops, the people give him food, entertain him.... That is one aspect of Ubuntu, but it will have various aspects. Ubuntu does not mean that people should not enrich themselves. The question therefore is: Are you going to do so in order to enable the community around you to be able to improve? ${ }^{26}$

Notice that Ubuntu, as an inherent-impulse-for-responsibility, precedes conventional morality. It is an event that precedes calculative thinking. People act without questioning whether it is right or wrong to give food to a "traveller." They simply give. They are acted upon by an inherent force. An example par excellence of Ubuntu, as an inherent-impulse-for-responsibility, is perceptibly reflected in the Biblical parable of the "Good Samaritan" (Luke 10:25-37). Unlike the Priest and the Levite who avoided tending to the agony of the wounded traveller, most likely due to the legal and moral frameworks of their time, the Good Samaritan spontaneously and unconditionally became ethically responsible for the half-dead traveller. The life of the other [traveller, stranger] took precedence over the Good Samaritan's societal laws and personal projects.

Underneath the ethics of Ubuntu is the intuitive conviction that mankind, under normal circumstances, is intrinsically good. Cruelty and other sorts of evils arise when the Ubuntu (humanness or goodness) in mankind is concealed by either choice or external factors. One whose Ubuntu is concealed becomes extremely egoistic and strives to manipulate other human beings and appropriate things for oneself. The concealment of Ubuntu is, most likely, what Thomas Hobbes saw as man's state of nature, where the solitary man becomes

\footnotetext{
${ }^{22}$ Kingsley N. Okoro, "Ubuntu Ideality: The Foundation of African Compassionate and Humane Living," Journal of Scientific Research \& Report 8, no.1(2015), 4.

${ }^{23}$ Claire Oppenheim, "Nelson Mandela and the Power of Ubuntu,"Religions 3 (2012), 370-371.

${ }^{24}$ Desmond Tutu, Believe: The Words and Inspirations of Desmond Tutu, Edited by Cameron Gibb, Annatjie Matthee \& Carolyn Lewis (Colorado: Blue Mountain Press, 2007), 3.

${ }_{25}$ Michael Battle, Reconciliation: The Ubuntu Theology of Desmond Tutu (Cleveland: The Pilgrim Press, 2009$), 5$.

${ }^{26}$ Nelson Mandela, “Experience Ubuntu Interview," interview by Tim Modise, video recording, May 24, 2006.
} 
a wolf to other men. ${ }^{27}$ Yet, without the concealment of Ubuntu, people are naturally good. For Mandela, all human beings, even those considered as the worst criminals, have "a core of human decency [Ubuntu]... if their heart is touched, they are capable of changing." ${ }^{28}$ Mandela further describes Ubuntu as "a streak of goodness in men that can be buried or hidden and then emerge unexpectedly..."29

In a nutshell, a humanistic response expressed through Ubuntu, describes an unconditional disposition or concern for the interests and welfare of others, regardless of their cultural, political, economic or religious differences. No human being is a foreigner to another. Human beings naturally share some common values and aspirations. For Kwame Gyekye, each human being has an inherent value that must be respected and appreciated at all times. ${ }^{30}$ This interpersonal appreciation has to be concretely made manifest in human virtues such as compassion, solidarity, generosity, hospitality, etc.

It should be noted, however, that a humanistic response does not seek to offer solutions to the problem of evil but rather to concretely create an environment that is likely to lessen both the intensity of human suffering and the possibility of the occurrence of evil. How is this so?

\section{Ubuntu as a Concrete Response to Human Suffering}

In the first place, Ubuntu, as an inherent-impulse-for-responsibility, challenges moral passivity or indifference when innocent lives are in danger. It obliges one to do something for the well-being of others in the face of human suffering. Mandela himself narrates that Ubuntu compelled him to begin a peaceful fight for the liberation of South Africans from the evils of apartheid. "There was no particular day on which I said, from henceforth I will devote myself to the liberation of my people; instead, I simply found myself doing so, and could not do otherwise." ${ }^{\prime 31}$ Notice that Ubuntu obsesses and pushes one into action. In the presence of moral or natural evils, Ubuntu spontaneously inspires compassion, love and solidarity with those who are suffering. It inspires sharing with those who are less privileged, taking care of the aged and other vulnerable human beings.

Secondly, Ubuntu inspires people to act in a supererogatory manner. A supererogatory act is one that goes beyond the call of duty (law), that is, over and above what a moral agent is required to do. Such an act is not based on the right of somebody. A genuine beggar has no right to one's help. But one finds oneself compelled to offer him or her some help. Some saints and heroes went beyond the call of duty by laying down their lives for others. A mother may transcend the duty of looking after her children by adopting an orphan child. The unconditional concern for others (Ubuntu) as reflected in human virtues of love, mercy, compassion, friendship...may lessen people's suffering, rather than clinging to legal justice which is fundamentally about, or crucially allied to, rights and duties.

Thirdly, in multicultural or multiracial societies, Ubuntu calls for harmonious co-existence. Human beings share a common humanity. For Mandela, the qualities shared by humanity are much more substantial than the differences that tend to divide people. ${ }^{32}$ The presencing of Ubuntu compels one to see one's neighbour as a brother or sister. It unlocks the spirit of togetherness. Self-realization is an outcome of one's reciprocated engagement with others. As people seek together a more meaningful co-existence, they realize that a relationship with one another based on compassion or friendship only is not enough. They thus see the need for just institutions to protect both individual and public goods, and to facilitate the distribution of duties and responsibilities.

\footnotetext{
27 Thomas Hobbes, Leviathan, or the Matter, Form, \& Power of a Common Wealth, Ecclesiastical and Civil (London: Andrew Crooke, 1651), Chap. 3.

${ }_{28}$ Nelson Mandela. Long Walk to Freedom: The Autobiography of Nelson Mandela, $1^{\text {st }}$ edition (New York: Hachette Book Group, 1994), 462.

29 Mandela. Long Walk to Freedom: The Autobiography of Nelson Mandela, 260-261.

${ }^{30}$ Kwame Gyekye, Tradition and Modernity: Philosophical Reflections on the African Experience (Oxford: Oxford University Press, 1997), 258.

31 Mandela. Long Walk to Freedom: The Autobiography of Nelson Mandela, 95. Apartheid is a political system of institutionalized racial and economic segregation. It existed in South Africa mainly between 1948 and 1994 under a government dominated by White Supremacists. Mandela eventually served as the country's first democratically elected black head of state from 1994-1999. Prior to his election, Mandela had served 27 years in prison because of his fight against apartheid.

32 Nelson Mandela, Foreword to Let Africa Lead: African Transformational Leadership for $21^{\text {st }}$ Century Business, by Reuel J. Khoza (Johannesburg: Vezubuntu, 2006), xxv.
} 
Fourthly and lastly, Ubuntu lays a philosophical basis for inclusive dialogue and respect for human life. The kind of dialogue promoted here aims at bringing ethics and politics together to prevent the occurrence of political evils such as abuse of power, corruption, killings, and many others. An inclusive dialogue draws on an intuitive conviction that every human being, however cruel, is inherently endowed with a streak of goodness. Everyone counts, and every life has hope. Thus, in societal deliberations, every voice must be heard. In moral or judicial dilemmas, consensual discernment is prioritized to tap the goodness in each human being. Ubuntu stirs peaceful resistance when injustices are being committed by those in power. Ubuntu prioritises the value of human life over other things.

But as mentioned earlier, Ubuntu, as an inherent-impulse-for-responsibility or "streak of goodness" in man, can be, sometimes, concealed or buried. The concealment of Ubuntu may be linked [among other things] to two key factors, namely, (1) intransigence in a society's moral or legal structures and (2) human egocentricity often linked with the human struggle for power or domination. Nevertheless, the spirit of Ubuntu is likely to spring from individuals whose educational system enables them to develop a significant level of ethical and religious consciousness. ${ }^{33}$ Individuals with ethical minds naturally and spontaneously tend to the needs of fellow human beings. Generosity becomes a habit for them. Also, a considerable level of religious consciousness may allow humans to listen to an inner voice that compels each one to become a brother or sister's keeper.

It has so far been argued that the problem of evil exceeds theoretical discourses and, in most cases, requires a humanistic response as expressed and concretised through the ethics of Ubuntu. But as mentioned earlier, a humanistic response does not offer a solution to the problem of evil, but can only contribute to lessening both the intensity of human suffering and the possibility of the occurrence of evil. Concretely speaking, the problem of evil remains a perpetual challenge to human existence. The risk of the occurrence of evil remains unavoidable. This straightforward fact raises an existential concern: How can one make one's life more meaningful despite the spectre of evil?

\section{Attitudinal Change towards Evil as Glimmer for Meaningful Existence}

"Attitudinal change" suggests a critical reorientation of the human mind towards the enigma of evil in the hope of achieving a meaningful existence. Meaningful existence entails a life lived with and for others in just institutions. It presupposes the availability of a combination of both material and spiritual goods.

"Attitudinal change" recommends a brave acceptance of the isness of things, i.e., the way reality presents itself to mankind. Human experience shows that there are things in life that may not be overturned despite all imaginable human efforts. Take the example of suffering as a result of old age, or death itself when all efforts have been exhausted to save a life. Some illnesses like HIV or certain cancers have also proven to defy the "zero tolerance" envisioned by medical experts. Could Covid-19 be one of these? The Bakiga people of Uganda say: Akeizire kemerwa (What has invincibly come your way must be bravely accepted). Also, reality [as perceived in concrete life] undergoes a continuous process of synthetisation. ${ }^{34}$ Cosmic nature has not ceased to mutate. Much as nature aims to its proper end [cosmic balancing], the possibility of causing harm to innocent people through its natural processes [e.g., earthquakes, volcanic eruptions, floods or storms] is always there. Human beings are naturally creative. Creativity is what defines life. Much as humans morally aim at creating what is good and life-giving, the possibility of the occurrence of evil [e.g., a medical operation that turns out to be fatal] is always there. The consequences of human creativity and cosmic (natural) processes can be either favourable or unfavourable to one's well-being and the well-being of others. This may explain why there are expressions like "good luck!" or "bad luck!" Without discouraging or undermining human ingenuity, mankind must acknowledge their impotence before certain human situations and cosmic forces. For believers, however, accepting these realities and surrendering them to God, can enable one to obtain supplementary "strength" and "wisdom" to either redress the situation [where possible], or to courageously face and cope with one's condition of needless suffering.

\footnotetext{
33 Bonaventure B. Gubazire, "Critical-Ethical-Thinking: A Humancentric Theory of Education in the Face of Labour-Market-

Schooling in Africa," E-Journal of Humanities, Arts and Social Sciences 2, no.6 (2021), 58.

34 Charles Hartshorne, “The Philosophy of Creative Synthesis," The Journal of Philosophy 55 (1958): 944-953.
} 
"Attitudinal change" also recommends an acknowledgement of the fact that human life is a continuous struggle for existence. Struggling involves an amount of suffering. A world without some suffering is unimaginable. It would even be boring. It would lack creativity and, perhaps, conceal the presencing of human goodness (Ubuntu). Indeed, human experience shows that most moral virtues such as courage, compassion, solidarity, generosity, care or even self-sacrifice, are only possible in an environment where there is suffering. This is the view carefully developed in the classical-theistic greater goods theodicy. ${ }^{35}$ Some suffering can enable mankind to achieve a higher level of moral and spiritual growth. In moments of suffering, God is the co-sufferer who understands and shares in human suffering to alleviate people's pain. Indeed, it is in the struggle towards the heights that one finds a sense in living. But, as previously argued, dehumanising evils such as genocide, terrorism, human slavery, corruption, starvation, material misery, etc., must not be justified at all costs. Significant measures must be put into place to continuously deter them or lessen the possibility of their occurrence. This is precisely why this study proposes a humanistic response to supplement classical theism in addressing such horrendous evils.

With a change of attitude towards human suffering, one may come to realise that a life worth living is a life of the mean, i.e., a life of the middle way between extremes. Too much of anything is poisonous. Modern capitalism tends to define and entice people to believe that material prosperity alone is what brings happiness to human societies. Countless men and women spend most of their time endlessly toiling to accumulate as much wealth as possible. Yet, human experience shows that too much material comfort is as much lifedestructive as the extreme lack of it. Extreme cases of self-gratification and self-mortification are equally dreadful. At the level of relationships, being extremely altruistic but completely neglecting oneself does not make sense. Moderation in all aspects of life seems to be the key to a meaningful existence.

"Attitudinal change" further recommends a joyful acceptance of human imperfection and fallibility. Fallibility lies in what Paul Ricoeur conceives of as a "split" in the nature of a human being. ${ }^{36}$ Mankind is always pulled between the demands of the body (pleasure) and the demands of the spirit (fulfilment). A human being, properly speaking, lies between being (existence) and nothingness (non-existence). A human being is fundamentally incomplete. Mankind is always in the making. This condition of incompleteness renders human beings fragile. It somehow explains why humans are prone to committing moral evil, and also prone to all sorts of addictions, coupled with the difficulty of quitting them. Human fallibility calls for humility, selfacceptance and mutual understanding. However, human fallibility should not be taken as a reason to justify evils committed by humans. It should also not be seen as an obstacle to a meaningful existence. Though naturally fallible, humans are graciously capable of actualising their potentials for a meaningful life. Again, by consenting and surrendering everything to God, one is likely to obtain supplementary "strength" and "wisdom" to make human life more meaningful.

Ultimately, "attitudinal change" recommends a courageous acceptance of human finitude (death). A generation comes and goes. Mankind is a pilgrim on earth. Life must come to an end at a particular moment. Consenting to this fact is "accepting" death as a "partner" in life. Consenting to the possibility of one's death is likely to liberate one from the fear of death. The secret of meaningful existence is to "die before you die" to realize that there is actually no death. ${ }^{37}$ Life and death are two sides of the same coin. Each side has its time. And now is the time to live. Let life $B e$ !

\section{CONCLUSION}

This study has attempted to examine the problem of evil through the lens of classical theism and has proposed a humanistic response, coupled with spiritual guidance, as supplementary to the classical-theistic teaching on evil. Classical theists consider God as having a hand in all that occurs in the Universe. Human suffering is seen as part of God's plan of salvation for mankind. Suffering can enable humans to develop certain virtues or a higher level of spiritual maturity. It was argued, however, that there are times when suffering becomes

\footnotetext{
${ }^{35}$ Hick, Evil and the God of Love, 231.

${ }^{36}$ Paul Ricoeur, "The Antinomy of Human Reality and the Problem of Philosophical Anthropology," Readings in Existential Phenomenology, Editors. Nathaniel Lawrence \& Daniel O’Connor (New Jersey: Prentice-Hall, Inc., 1967$), 391$.

37 Eckhart Tolle, The Power of Now: A Guide to Spiritual Enlightenment (California: Namaste Publishing \& New World Library, 2004), 46.
} 
extremely dehumanising that any attempt to theoretically justify it in terms of God's divine wisdom fails to make sense in the lives of people. In view is this, this paper modestly recommends a humanistic response [concretised through the African ethics of Ubuntu] as a supplementary approach in addressing concrete situations of needless human suffering. Since a humanistic response can only lessen the intensity of human suffering and the possibility of the occurrence of evil, this paper further recommends a change of attitude towards the phenomenon of evil. Human life is a continuous struggle for existence. There are things in life that transcend human ingenuity and human intelligibility. Thus, a courageous acceptance of such things may enable one [believer in God or not] to find a taste in life in the midst of human suffering. For believers, surrendering to God may enable them to obtain supplementary "strength" and "wisdom" to redress situations of gratuitous suffering [where possible], or to squarely face them and bravely cope with them. It must be acknowledged, however, that the problem of evil goes beyond human understanding. Human life and human suffering appear to be mysteriously inseparable. As such, this study is, but a drop in the ocean.

\section{ABOUT AUTHOR}

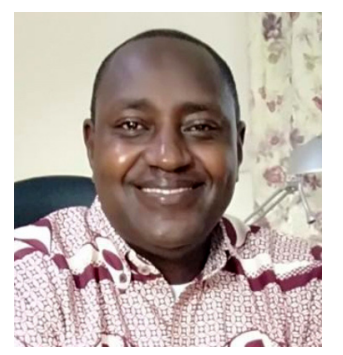

Bonaventure B. Gubazire is currently a Lecturer in Philosophy and serves as Dean of Students at Spiritan University College-Ejisu (Ghana). He is a Catholic priest belonging to the Society of Missionaries of Africa (M. Afr). He holds a Ph.D. in Philosophy and has lectured in some other Universities. He has published a number of scholarly material and presented academic papers in various universities in and outside Africa. His research interests are focused on Education, Ethics and Religions (Metaphysics).

\section{BIBLIOGRAPHY}

Adams, Marilyn McCord. Horrendous Evils and the Goodness of God. Ithaca and London: Cornell University Press, 1999.

Aquinas, Thomas. Summa Theologica. Translated by Fathers of the English Dominican Province. Westminster: Christian Classics, 1981.

Augustine. On the Free Choice of the Will, On Grace and Free Choice, and Other Writings. Edited and translated by Peter King. Cambridge: Cambridge University Press, 2010.

Augustine. Saint Augustine Confessions. Translated by R.S. Pine-Coffin. Harmondsworth: Penguin Books Ltd, 1973.

Battle, Michael. Reconciliation: The Ubuntu Theology of Desmond Tutu. Cleveland: The Pilgrim Press, 2009.

Chrzan, Keith. "When is a gratuitous evil really gratuitous?" International Journal for Philosophy of Religion 24:1/2 (July-September 1988): 87-91.

Gab, Sebastian. "Why do we suffer? Buddhism and the Problem of Evil." Philosophy Compass 10, no.5 (2015): 345-353.

Gubazire, Bonaventure B. "Critical-Ethical-Thinking: A Humancentric Theory of Education in the Face of Labour-Market-Schooling in Africa." E-Journal of Humanities, Arts and Social Sciences 2, no.6 (2021): 52-60.

Gyekye, Kwame. Tradition and Modernity: Philosophical Reflections on the African Experience. Oxford: Oxford University Press, 1997.

Hartshorne, Charles. "The Philosophy of Creative Synthesis." The Journal of Philosophy 55 (1958): 944-953.

Hasker, William. "The Problem of Evil in Process and Classic Free Will Theism." Process Studies 29, no.2 (2000): 194-208.

Hick, John. Evil and the God of Love. Second Edition. New York: Palgrave Publisher Ltd, 1985.

Hobbes, Thomas. Leviathan, or the Matter, Form, \& Power of a Common Wealth, Ecclesiastical and Civil. London: Andrew Crooke, 1651.

Irenaeus. Saint Irenaeus of Lyons: Against Heresies. Indiana : Ex Fontibus Company, 2020. 
Kerkegaard, Soren. Upbuilding Discourses in Various Spirits. Ed. Edna Hong. Princeton: Princeton University Press, 2009.

Kushner, Harold S. When Bad Things Happen to Good People. New York: Christian Book Distributors, 2014.

Mandela, Nelson R. Long Walk to Freedom: The Autobiography of Nelson Mandela. $1^{\text {st }}$ edition. New York: Hachette Book Group, 1994.

Mandela, Nelson R. "Experience Ubuntu Interview." Interview by Tim Modise. Video recording. 24 May 2006. Available from https://en.wikipedia.org/wiki/Ubuntu_philosophy. 14 March 2019.

Nietzsche, Friedrich. "Epigrams and Arrows 8." Twilight of Idols. Translator. Richard Polt. Indianapolis: Hackett Publishing Company, Inc.1997 [1889].

Okoro, Kingsley N. "Ubuntu Ideality: The Foundation of African Compassionate and Humane Living." Journal of Scientific Research \& Report 8, no.1 (2015):1-9.

Oppenheim, Claire. "Nelson Mandela and the Power of Ubuntu." Religions 3 (2012): 369-388. Article on line. Available from https://doi.org/10.3390/rel3020369. 14 March 2019.

Plantinga, Alvin. God, Freedom, and Evil. New York: Eerdmans, 1974.

Purino, Marie Majorie R. 'On Wisdom: Revisiting Chandogya Upanishad, Cusanus' Visio Intellectualis, and Heidegger's Aletheia.” PHAVISMINDA Journal 14 (May 2015): 59-79.

Ricoeur, Paul. "The Antinomy of Human Reality and the Problem of Philosophical Anthropology." Readings in Existential Phenomenology. Editors. Nathaniel Lawrence \& Daniel O'Connor. New Jersey: Prentice-Hall, Inc., 1967.

Swinburne, Richard. Providence and the Problem of Evil. Oxford: Oxford University Press, 1988.

Tolle, Eckhart. The Power of Now: A Guide to Spiritual Enlightenment. California: Namaste Publishing \& New World Library, 2004.

Tutu, Desmond. Believe: The Words and Inspirations of Desmond Tutu. Edited by Cameron Gibb, Annatjie Matthee \& Carolyn Lewis. Colorado: Blue Mountain Press, 2007. 